\title{
Are Taxes a Critical Factor for Innovative Companies Created by Females?
}

Submitted 13/02/21, $1^{\text {st }}$ revision 15/03/21, $2^{\text {nd }}$ revision 40/4/21, accepted 26/05/21

\section{Mercedes Barrachina ${ }^{1}$, Maria del Carmen García Centeno ${ }^{2}$, Carmen Calderón Patier ${ }^{3}$}

\begin{abstract}
:
Purpose: This paper focuses on evaluating the effect of taxes and business costs in innovative female entrepreneurial activities.

Design/Methodology/Approach: The research has been performed using the data from different databases: Global Entrepreneurship Monitor (GEM), Organisation for Economic Co-Operation and Development (OECD) and World Bank Doing Business (WBDB) databases for the period 2011-2015, having in scope the OECD countries. The main model utilized is a Logit regression using the innovative company variable as the independent variable.

Findings: There are variables that directly influence the decision of creating an innovative company such as the age influencing in a negative way, the older the potential entrepreneur, the less possibility of acting as an entrepreneur in an innovative company, the previous experience in founding other companies, independently of the sector and type, the confidence or the opportunities identified. Income tax and the cost of the business procedures are affecting women negatively when deciding to start a new innovative company.

Practical Implications: The results could be useful for governments, that in the post COVID time, will decide to enhance and facilitate economy, especially considering how to modify the tax structure with the main purpose of increasing entrepreneurial activity because this will increase economic growth and job creation.

Originality/Value: The analysis contributes to the literature by extending the knowledge of the characteristics behind the female entrepreneurship and exposes the key factors affecting the process of creating innovative business companies, specifically by women.
\end{abstract}

Keywords: Innovative entrepreneurship, female entrepreneurship, taxes, GEM, OECD countries.

JEL codes: M13, M20, M21.

Paper Type: Research study.

${ }^{l}$ CEINDO, Law and Economics Program, San Pablo CEU University, Madrid, Spain.

Email: mar.barrachina.ce@ceindo.ceu.es

${ }^{2}$ San Pablo CEU University, Madrid, Spain. Email: garcen@ceu.es

${ }^{3}$ San Pablo CEU University, Madrid, Spain. Email: calder@ceu.es 


\section{Introduction}

Entrepreneurship is of great importance in the economy and in global society and is being a hot topic for interested public decision makers due to its growing importance in economic activity (Thurik, 2014). According to various studies, entrepreneurship creates employment, boosts competitiveness and actively participates in the modernization of the economy (Romero and Milone, 2016; Hoskisson et al., 2011; Bird et al., 2012; Carlsson et al., 2013). There are multiple measures related to entrepreneurship, however, many studies and policymakers usually utilize the business entry-rate as an important indicator of the entrepreneurial activity (Ferede, 2018). Different national governments reports analyze the evolution of the business entry-rate to have an overview of the behavior of the entrepreneurial activity in their area.

Taxes are critical for the sustainability of public finances and they are key to transform societies as they are the collective price paid for public goods and services. In some way, taxes play an important role affecting both supply and demand factors, depending on the incentives established. There are important taxes differences between the multiple countries of the world. According to the Taxation Trends in the European Union Report from 2019, the European Union Tax Revenues remain high (39\% of the GDP, in average) compared with other advanced economies, as it is around $11.9 \%$ of the GDP above the level for the United States, and also $8.5 \mathrm{pp}$ above the level for Japan.

There are different economic models that justify that personal income tax system could, potentially, influence entrepreneurial activities in several different ways. In one hand, higher income tax could impact reducing entrepreneurship, due to its risky nature, and therefore, entrepreneurs are affected by paying taxes on all their incomes when they have success. On the other hand, there are other researches that justify that entrepreneurs have more tax planning opportunities and that the potential taxsavings benefits could increase with the income tax rate, therefore, higher income tax rate can encourage entrepreneurship, even considering a non-productive entrepreneurial activity. These aspect will be analyzed in the next section.

In general, the tax system is a great dilemma for the governments as it is supposed to directly affect different economic areas. There are specific concrete key principles that should affect the tax system in relation to entrepreneurship: neutrality and modesty. At the same time, tax systems are usually complex, and there are different interests, especially political interests that are continuously increasing their complexity (Elert et al., 2019).

This paper is organized as follows: next section identifies state of the art by reviewing main literature associated with the topic in the scope of the investigation. Third section analyzes the data utilized and describes as well as the method used for 
this analysis. Fourth section shows the main results obtained. Finally, main conclusions are summarized, and the references are listed.

\section{Literature Review}

Taxes are an important fact in the economy of the countries and governments are concerned about the impact they could have in the population but also in the businesses. A decrease or increase in taxes could directly affect different economic variables, such as, the Gross Domestic Product (GDP), the employment rate, the public debt, etc, and of course to the monetary politics. Therefore, it is key to analyze in detail the potential effect in the interested area before taken any decision.

In the literature there are different analyzes evaluating the effect of taxes in the economy, to verify the effect of decreasing corporate taxes and personal income taxes (Macek, 2014). The mentioned author concluded that the economy is stimulated with lower corporate taxation and lower income taxes. There are other studies which review the models that describe the effect of taxation in the economic growth (Myles, 2000). OECD studies suggest that "an increase in the average tax rate of about $10 \%$ over the past 35 years may have reduced OECD annual growth rates by 0.5 percentage point" (Leibfritz et al., 1997).

Specifically related to entrepreneurship, there are several researches in the literature that are focused on analyzing the effect of the different types of taxes on potential variables directly related to the entrepreneurship. According to logic, it seems to exist a negative relationship between corporate taxes and innovation entrepreneurship. For example, Darnihamedani et al. (2018), suggested the negative relationship between corporate taxes with innovative entrepreneurship, meanwhile, he also found that there was not a clear relationship between income taxes and innovative entrepreneurship. Other authors perform different reviews of the available literature (Clingingsmith and Shane, 2016) finding that there is no evidence of consensus on the effects of individual income tax policy on entrepreneurship due to the complexity of connection mechanisms between tax policy and the entrepreneurial decision-making process.

The European Commission is an institution that has published different reports related to taxes and there are different reports that explore the possibility of simplifying the tax compliance procedures for SMEs (European Commission, 2007). In this report, it is possible to find interesting conclusions, such as, that penalty procedures can be avoided or reduced with special information programs for young enterprises, that tax forms and reporting requirements can be adjusted to the business reality of small enterprises or that there are binding interpretations of existing tax laws and rulings reduce uncertainty.

Analysis related to the effect of taxes on entrepreneurship is complex to be developed as there is no specific tax on income coming from entrepreneurial 
activities in United States, Europe or any other region. The taxes related to entrepreneurial activities are reflected in the labor income, business income, current capital income...etc. (Elert et al., 2019).

There are researchers who justify that there are specific differences in the tax treatment of profits and losses that could potentially have effects on the incentives to select a riskier occupation (Cullen and Gordon, 2007). Other studies are focused on the state taxes, for example, the study developed in United States (Bruce and Deskins, 2012), analyzing the level of entrepreneurship in the different states. They compared each state's corporate, personal income and sales taxes rates, as well as economic development incentives and rules governing multi-firm and multi-state operations. They found that the state tax rates have no effect on a state's small business activity and they also recommend simplifying the tax system to create a more neutral and productive tax environment.

Other authors defend that having a tax system focused on high labor taxes and low profit taxes, induces a significant proportion of agents to become entrepreneurs, however, they also conclude that this kind of economies could potentially, worsen the situation for the majority of the workers, leading to a conflict between efficiency and equality (Schetter et al., 2019).

There are specific research studies based on the analysis of the taxes, being recurring costs, the reason for reducing the "prize" of innovation and the profit from entrepreneurship, discouraging individuals with innovative business ideas from becoming entrepreneurs (Darnihamedani et al., 2018).

Other studies found in the literature are focused on discussing several mechanisms in which capital gains taxes can affect entrepreneurs' decisions (Gentry, 2010). Main mechanisms are based on, first, the fact that capital gains taxes could potentially create an additional level of taxation on successful entrepreneurs. They are also based on, second, the asymmetric taxation of capital gains and losses, indicating that the asymmetries in the tax system could be an important fact for discouraging entrepreneurs from taking risks with an entrepreneurial activity. Third, capital gain taxes can directly affect the cost of capital for entrepreneurs.

There are research studies that justify that high or distortive taxes and heavy labor market regulations reduces high-impact entrepreneurship (Henrekson et al., 2010), reasoning also that lower taxes on entrepreneurial activities may have less effect than expected if high taxes on skilled labor give rise to bottlenecks in production or if key areas remain closed for entrepreneurial exploitation. Related to the personal income tax, there are different studies and theories in the literature. It is interesting the study from Ferede (Ferede, 2019), that suggests that the top income tax rate has a negative and statistically significant effect on entrepreneurship considering short term and long-term time period. 
Focusing the analysis on corporate taxes, according to empirical evaluations, the relation between corporate income taxes and entrepreneurship is stronger than the relationship between other taxes and entrepreneurship. Moreover, higher corporate income tax rates reduce entrepreneurship entry rates, concluding also that reductions in the corporate income tax rate may only affect entrepreneurship rates below a specific threshold tax level (Block, 2016). According to several studies, there a significant negative effect of corporate income taxation on entry rates (Da Rin et al., 2011). Creating employment is a key topic when evaluating the effect of entrepreneurship. In line with Carroll et al. (1996), individual income taxes have a statistically and quantitatively significant effect on the probability of creating employment.

\section{Data and Method}

This study is performed using both individual-level and country-level data. In one hand, considering the analysis at individual-level, the data is extracted from a unique source, which is the Global Entrepreneurship Monitoring (GEM) database. This database is the world's foremost study of entrepreneurship, that started as a project from the Babson College (USA) and the London Business School (UK) with the main purpose of evaluating the different factors that affect entrepreneurship. The data used for the creation of the mentioned database is collected from two different surveys, the Adult Population Survey (APS) and the National Expert Survey (NES). The first one, the APS is based on the answers from at least 2.000 adults of the country in scope and evaluates the entrepreneurial aspirations of the respondents. The second one, surveys a group of business experts as well as academic experts to measure the institutional factors that affect entrepreneurship. For the study scope, only data from the APS will be utilized.

In the other hand, considering the analysis at country-level, the data is extracted from two different sources, the World Bank Doing Business (WBDB) database and the OECD database. First, the World Bank Doing Business Database is a project that provides with measures related to regulations and their enforcement across 190 economies. This database provides quantitative indicators covering 12 areas of the business environment, mainly related with the effects of business regulation, removing obstacles to entrepreneurship, employing workers, contracting with the government and the ease of doing business. Several studies have been performed in the past related to this database to mainly evaluate regulatory influences on the productivity and in the entrepreneur's behavior (Dreher and Gassebner, 2013; Braunerhjelm and Eklund, 2014). Second, the OECD Database is composed of more than 800 different databases containing related data from the OECD countries, in several different topics, such as economy, education, finance, government, health, innovation and technology, jobs or society. This database contains information, at least, from the last 10 years for the mentioned countries. 
In Table 1, the different variables utilized are detailed. Considering the analysis performed, the dependent variable is innovative entrepreneur (sunewcst), which measures the innovation in the service provided by the entrepreneur, and it is extracted from the GEM database. This is a dummy variable, taken the value 1, if the entrepreneur considers that his product/service is new to the consumer or it takes value 0 , if the he/she considers it is not a new service/product.

Different control variables are used in the individual-level analysis: education level (uneduc), entrepreneurial network (knowent), good opportunity consideration (opport), perception entrepreneurial skills (suskill), prior experience in entrepreneurship (discent), age (age), age squared $\left(\mathrm{age}^{2}\right)$ and the industry of the business (IND_TRANS, IND_CONS, IND_EXTRACT, IND_SERV). At country level, there are different control variables considered: Gross Domestic Product (GDP), the level of population aged between 25 and 34 years old (tertiary_education). Finally, the variables related to the taxes are included: the cost of the procedure of starting a business (cost_buss_proc), and different tax information, corporate taxes (corporate_tax), income taxes (income_tax).

Table 1. Variables used in the analysis

\begin{tabular}{|c|c|c|c|c|c|}
\hline Level & Category & Variable & Description & Type & Source \\
\hline \multirow{7}{*}{$\begin{array}{l}\text { Individual } \\
\text { GEM }\end{array}$} & Educational & Uneduc & $\begin{array}{l}\text { The variable takes the value } 1 \text { if the } \\
\text { entrepreneur has university education, } \\
\text { and } 0 \text { in any other case }\end{array}$ & Dummy & GEM \\
\hline & \multirow{3}{*}{ Perceptual } & Knowent & $\begin{array}{l}\text { The variable takes the value } 1 \text { if the } \\
\text { entrepreneur personally, knows } \\
\text { someone who started a firm in the } \\
\text { past two years and } 0 \text { in any other case }\end{array}$ & Dummy & GEM \\
\hline & & Opport & $\begin{array}{l}\text { The variable takes the value } 1 \text { if good } \\
\text { opportunities for starting a business } \\
\text { would exist in the residential area } \\
\text { within the } 6 \text { months following the } \\
\text { survey and } 0 \text { in any other case }\end{array}$ & Dummy & GEM \\
\hline & & Subskill & $\begin{array}{l}\text { The variable takes the value } 1 \text { if the } \\
\text { person interviewed believe to have } \\
\text { the knowledge, skill and experience } \\
\text { required to start a business and } 0 \text { in } \\
\text { any other case }\end{array}$ & Dummy & GEM \\
\hline & $\begin{array}{l}\text { Entrepreneu } \\
\text { rial } \\
\text { experience }\end{array}$ & Discent & $\begin{array}{l}\text { The variable takes the value if the } \\
\text { individual has experienced a business } \\
\text { failure in the } 12 \text { months preceding the } \\
\text { survey and } 0 \text { in any other case }\end{array}$ & Dummy & GEM \\
\hline & Personal & age, age ${ }^{2}$ & age of the entrepreneur & Numeric & GEM \\
\hline & Industry & $\begin{array}{l}\text { IND_TRA } \\
\text { NS, } \\
\text { IND_CON } \\
\text { S, } \\
\text { IND_EXT } \\
\text { RACT, } \\
\text { IND_SER } \\
\text { V } \\
\end{array}$ & $\begin{array}{l}\text { industry of the business analyzed } \\
\text { (transforming, consuming, extraction } \\
\text { and services areas) }\end{array}$ & Dummy & GEM \\
\hline Country & Finance & GDP & $\begin{array}{l}\text { Gross Domestic Product, measured as } \\
\text { nominal GDP in US dollars per capita }\end{array}$ & Numeric & $\begin{array}{l}\text { OECD } \\
\text { Database }\end{array}$ \\
\hline
\end{tabular}




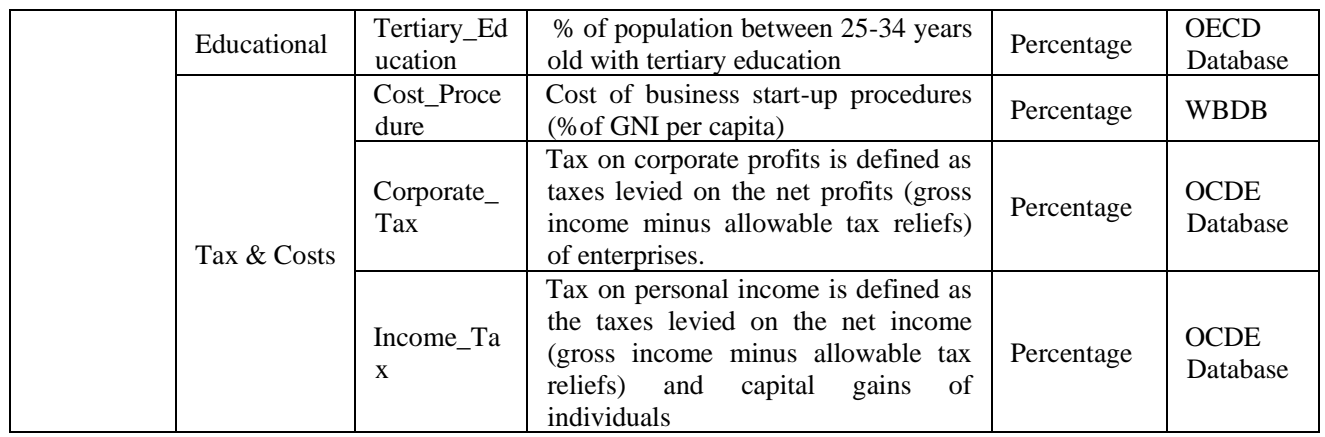

Source: Authors.

\subsection{Data Details}

This analysis is focused on the OECD countries, in this case, covering a total of 30 different countries in the period 2011-2015, containing 420.985 registers. The most recent data available in the GEM database has been included, that is the reason to consider the last 4 years available. This data contains the answers to the survey from individuals aged 18 to 64 entrepreneurs, employees, unemployed individuals, students and retirees. When filtering this data for female individuals, the number of registers is limited to 214.720 registers. As this study focuses on innovative female entrepreneurs, consequently, the data has been filtered to consider the variable TEA being equal to 1 , having analyzed a total of 14.052 registers.

\subsection{Method}

The method used for the analysis was a logit regression, in which the dependent variable is the sunewcst. This variable quantifies if the product offered by the entrepreneur is considered new or not. Sunewcst is equals to 0 if the product offered is an imitation and it is equals to 1 if the product offered is new. The purpose of this analysis is to identify the factors that make a female nascent entrepreneur more likely to be innovative in any potential way, evaluating the effect of the taxes in the decision to become entrepreneur. Therefore, individual and country level are included in this model and the details of the different variables can be found in the below equation:

$$
\begin{aligned}
& \text { sunewest }=\alpha+\beta_{1} \text { age }+\beta_{2} \text { age }{ }^{2}+\beta_{3} \text { uneduc }+\beta_{4} \text { knowent }+\beta_{5} \text { opport }+\beta_{6} \text { suskill } \\
& +\beta_{7} \text { discent }+\beta_{9.1} \text { IND_TRANS }+\beta_{9.2} \text { IND_CONS }+\beta_{8.3} \text { IND_EXTRACT } \\
& +\beta_{9.4} \text { IND_SERV }+\beta_{9} \text { gdp }+\beta_{10} \text { tertiory_education } \\
& +\beta_{11} \text { cost_procedure }+\beta_{12} \text { tertiary_education }+\beta_{13} \text { corp_taxes } \\
& +\beta_{14} \text { income_tax }+\varepsilon
\end{aligned}
$$




\section{Analysis and Results}

In this case, the analysis performed focuses on performing an evaluation based on a logit model for the OCDE countries, using sunewcst as the independent variable and taking into account that the data have been filtered to focus the evaluation only on identifying female entrepreneurship in the countries in scope. The OCDE countries with data available for the period analyzed and therefore included in the analysis have been: Austria, Canada, Chile, France, Germany, Greece, Ireland, Israel, Italy, Japan, Korea, Luxembourg, Netherlands, Poland, Slovak Republic, Slovenia, Spain, Sweden, Switzerland, Turkey, United Kingdom and United States. To start with the analysis, a descriptive analysis was performed (Table 2).

Table 2. Result from descriptive analysis on the variables utilized

\begin{tabular}{lllll}
\hline Variables & Results & & & \\
\hline Parameter & Min & Max & Mean & St.Dev. \\
Age & 17 & 91 & 40.151 & 12.01 \\
age ${ }^{2}$ & 289 & 8281 & 1756.56 & 1033.65 \\
Discent & 0.00 & 1.00 & 0.06 & 0.24 \\
Subskill & 0.00 & 1.00 & 0.79 & 0.40 \\
Opport & 0.00 & 1.00 & 0.50 & 0.50 \\
Knowent & 0.00 & 1.00 & 0.62 & 0.48 \\
Uneduc & 0.00 & 1.00 & 0.33 & 0.47 \\
income_tax & 1.38 & 13.39 & 6.34 & 3.48 \\
corp_tax & 1.19 & 10.75 & 2.93 & 1.26 \\
cost_busi_proc & 0.00 & 20.7 & 5.35 & 5.55 \\
GDP & 16.546 .64 & 103788.0 & 34839.14 & 14708.67 \\
tertiary_education & 18.79 & 65.6 & 36.23 & 10.09 \\
IND_TRANS & 0.00 & 1.00 & 0.15 & 0.36 \\
IND_CONS & 0.00 & 1.00 & 0.58 & 0.49 \\
IND_EXTRACT & 0.00 & 1.00 & 0.03 & 0.18 \\
IND_SERV & 0.00 & 1.00 & 0.19 & 0.19 \\
\hline
\end{tabular}

Source: Own elaboration.

This initial analysis, reflected in Table 2, suggests that the average age for the female participating in the survey was 40.15 , that approximately the $80 \%$ of the respondents considered that they had the experience and skills to start a business and that on average, $36.23 \%$ of the respondents have a tertiary education level. The consume area is in the industry the higher respondents (58\%). Related to the taxes, income tax has a minimum value of 1.38 (Chile, 2011), meanwhile the maximum value is 13.39 (Finland, 2014). Moreover, for the corporate taxes level, there is a significant differences between the countries analyzed. Minimum value identified is 1.19 (Slovenia, 2013), meanwhile the maximum value in the data analyzed is 10.75 (Norway, 2011). The cost for the business procedures is having an average value of 5.35, but with a minimum and maximum values of 0 (Slovenia, 2011-2014) and 20.7 (Greece, 2011), respectively. 
A logistic regression model (Logit) is used focusing the analysis on female innovative venture creation. The software used for this analysis is a free and opensource distribution for the Python programming languages, which is called "Anaconda". From the run model with the commented Python software, the coefficient value and p-value were obtained. Table 3 presents the results obtained for each variable from the data in the scope of this work.

Table 3. Result from the logit model for female innovation venture creation analysis

\begin{tabular}{lll}
\hline Variables & Results & \\
\cline { 2 - 3 } Parameter & Coefficient & P-value \\
age & -0.0371 & $0.0000^{* *}$ \\
age & 0.0004 & $0.0008^{* *}$ \\
discent & 0.4116 & $0.0000^{* *}$ \\
subskill & 0.1945 & $0.0000^{* *}$ \\
opport & 0.4487 & $0.0000^{* *}$ \\
knowent & 0.0389 & 0.3259 \\
uneduc & 0.2079 & $0.0000^{* *}$ \\
income_tax & -0.1705 & $0.0000^{* *}$ \\
corp_tax & 0.1881 & $0.0000^{* *}$ \\
cost_busi_proc & -0.0245 & $0.0000^{* *}$ \\
GDP & $0.4495^{*}$ & $0.0000^{* *}$ \\
tertiary_education & -0.0103 & $0.0030^{* *}$ \\
IND_TRANS & 0.71 & $0.0022^{* *}$ \\
IND_CONS & 0.68 & $0.0028^{* *}$ \\
IND_EXTRACT & -0.064 & 0.8013 \\
IND_SERV & 0.4075 & 0.0810 \\
\hline
\end{tabular}

* calculated with the logarithm ${ }^{* *}$ Significant at 5\%

Source: Own study.

The $\mathrm{R}$ value obtained in this model is 0.089 , which a value in line with similar results obtained in the literature (Mohammadi Khyareh, 2018). According to the results obtained, it can be concluded that in the study of the influence of the most relevant factors that affect female innovative startup creation, for all countries analyzed, age (age variable) has a negative and significant influence, while age squared (variable $\mathrm{age}^{2}$ ) is a significant variable with a positive influence, which implies that the older the women, the less possibility of acting as an entrepreneur of an innovative company. The relationship between the decision to become a female innovate entrepreneur and the age has a quadratic relationship, in other words, the mentioned relationship is decreasing at increasing rates.

Evaluating the variable related to tertiary education (variable tertiary_education), it is observed that the mentioned variable significant and that, contrary to what might be expected, it affects negatively to the decision of founding an innovative company. In the literature there is evidence that shows that if the education provided to women is closely related to entrepreneurship, then, the better trainings received, then better 
results obtained when becoming entrepreneur (Bhardwaj, 2014; Razmi and Firrozabadi, 2016).

One of the highest coefficients in the results obtained (not considering the variables closely related to the industry) is associated with the variable related to having experience in entrepreneurship (variable discent) by failing in the past in the management of a startup. The mentioned variable is significant and with a positive coefficient, with an absolute value of 0.4 .

The different variables considered in the analysis and related to taxes and costs (income_tax, corp_tax, cost_busi_proc) are obtained to be significant, however, they have different coefficients. The variable related to the income tax (income_tax), affects negatively to women the decision of founding an innovative company, however, the corporate taxes (corp_tax), affects positively, which means that the higher the corporate taxes, the higher the propensity to create an innovative company. Finally, the costs of business procedures (cost_busi_proc) is the last variable analyzed belonging to this group, and it also affects in a negative way.

Confidence, represented in the analysis with the suskill variable, is a significant variable, and as expected, the influence is positive, with an absolute value of 0.1945. The variable opport, which mainly reflects the perception of good opportunities to start a business in the living area, it is a significant variable, affects the propensity of starting an innovative way in a positive way, and has the highest coefficient of all the variables analyzed.

Knowing other entrepreneurs (knowent variable) is not a significant variable in the case of female considering starting an innovative company. The variable related to the Gross Domestic Product (GDP) was found to be significant, and the coefficient is positive, so it is affecting positively to the decision of creating an innovative company. Finally, for the area in which the business is enclosed, it is possible to find that for innovative business, the sector (IND_TRANS and IND_CONS) is a significant variable when it is related to transforming or consumer oriented areas, having a positive influence.

\section{Conclusions}

The analysis performed has evaluated the influence of the taxes in the female innovative companies' creation process in the OECD countries considering the period 2011-2015 and evaluating the available data for the mentioned countries. This analysis is interesting due to the lack of exhaustive details about innovative companies created by women in the different entrepreneurial ecosystems.

This analysis contributes to the literature by extending the knowledge of the characteristics behind the female entrepreneurship and exposes the key factors affecting the process of creating innovative business companies, specifically, by 
women. As suggested, there are variables that directly influence in the decision of creating an innovative such as the age, influencing in a negative way, the older the potential entrepreneur (the less possibility of acting as an entrepreneur in an innovative company),such as the previous experience in founding other companies, independently of the sector and type, such as the confidence or such as the opportunities identified.

Failing in the past when starting a business is a key variable when analyzing the profile of the women who have started innovative companies. Therefore, the support from the institutions to female who have failed in the creation of a company is key to help innovative companies to be created. There are different national and regional governments (Spain, Sweden, or Germany) who have provided financial help to founders of failed business with the purpose of giving them a second chance and to promote entrepreneur from people with experience in entrepreneurship and lessons learnt from the entrepreneurial trials.

Related to taxes, the income tax and the cost of the business procedures are clearly affecting negatively to women when deciding to start a new innovative company. These results are in line with the analyzed literature (Baliamoune-Lutz and Garello, 2014), justifying that the income tax progressivity at higher-than average incomes have a robust negative effect on nascent entrepreneurship.

Related to corporate taxes, according to the data analyzed, it affects positively to the decision of women to start a new business, meaning that the higher the corporate taxes, the higher the propensity to start an innovative business. These results are in line with the obtained by Venancio et al. (2020) justifying that higher corporate taxes impact positively on entrepreneurship. According to other authors found in the literature, corporate taxes affects negatively to the entrepreneurship entry rates (Block, 2016), however other authors justify that it is difficult to conclude the effect of corporate taxes in entrepreneurship (Carroll et al., 1996).

There are several limitations to the results of this study. First, this analysis has been performed considering 3 different databases and for specific countries, incomplete information was found for the period analyzed. Second, another important limitation to be highlighted is the measure utilized for measuring the innovation in this study, as this is based on a variable that is self-reported, and that could be biased by the respondent's opinion. Third, this study has tried to perform a simplification of the taxes to homogenize the taxes, when it is very difficult to try to unify the tax structure of the different nations involve. Fourth, the data used in this study was based on the most recent available data (period 2011-2015) and to get a more recent analysis the information from the last years.

As a summary, main conclusion includes that taxation is a key parameter when women deciding to fund an innovative business. Another key fact is that it is essential to consider the complete fiscal system (corporate taxes, personal taxes, cost 
of business procedures...etc.) when female entrepreneurs decide to start a new business. Those results could be useful for governments, that in the post COVID time, will decide how to enhance and facilitate economy, especially considering how to modify the tax structure with the main purpose of increasing entrepreneurial activity because this will increase economic growth and job creation.

Futures lines for investigation could be focused on analyzing how the different female policies, labor regulation or national measures impact in the decision of starting an innovative company. Another potential topic that could be researched is related to the relationship between the success of the company and the level of taxes during its existence. Moreover, as access to credit is a key topic when starting a new business, a deeper analysis of the level of necessity for starting an innovative business, considering the different business, could be another interesting topic to investigate to provide answers and arguments to the policymakers and regulators to adapt the policies, procedures and regulations to obtain an efficient economy.

\section{References:}

Baliamoune-Lutz, M., Garello, P. 2014. Tax structure and entrepreneurship. Small Business Economics, 42, 165-190.

Bhardwaj, B. 2014. Impact of education and training on performance of women entrepreneurs: A study in emerging market context. Journal of Entrepreneurship in Emerging Economies, 6(1), 38-52.

Bird, B., Schjoedt, L., Baum, J.R. 2012. Editor's introduction. Entrepreneurs' behavior: Elucidation and measurement. Entrepreneurship Theory and Practice, 36(5), 889913.

Block, J. 2016. Corporate income taxes and entrepreneurship. IZA World of Labor 2016: 257. doi: 10.15185/izawol.257.

Braunerhjelm, P., Eklund, J.E. 2014. Taxes, tax administrative burdens and new firm foundation. Kyklos, 67(1), 1-11.

Bruce, D., Deskins, J. 2012. Can state tax policies be used to promote entrepreneurial activity? Small Business Economics, 38, 375-397.

Carlsson, B., Braunerhjelm, P., McKelvey, M., Olofsson, Ch., Persson, L., Ylinenpää, H. 2013. The evolving domain of entrepreneurship research. Small Business Economics, 41, 913-930.

Carroll, R., Holtz-Eakin, D., Rider, M., Rosen, H. 1996. Income Taxes and Entrepreneur' Use of Labor. Working Papers 752, Princeton University, Department of Economics, Industrial Relations Section.

Clingingsmith, D., Shane, S. 2016. How Individual Income Tax Policy Affects Entrepreneurship. Fordham Law Review, 84(6), 2495-2516.

Cullen, J.B., Gordon, R.H. 2007. Taxes and entrepreneurial risk-taking: theory and evidence for the U.S. Journal of Public Economics, 9(7), 1479-1505.

Dreher, A., Gassebner, M. 2013. Greesing the wheels? The impact of regulations and corruption on firm entry. Public Choice, 155(3), 413-432.

Da Rin, M., Di Giacomo, M., Sembenelli, A. 2011. Entrepreneurship, Firm Entry, and the Taxation of Corporate Income: Evidence from Europe. Journal of Public Economics, 95(9), 1048-1066.

Darnihamedani, P., Block, J.H., Hessels, J., Simonyan, A. 2018. Taxes, start-up costs, and 
innovative entrepreneurship. Small Business Economics, Springer, 51(2), 355-369.

Elert, N., Henrekson, M., Sanders, M. 2019. Taxation and Entrepreneurship. In: The Entrepreneurial Society. International Studies in Entrepreneurship, Vol 43. Springer, Berlin, Heidelberg. https://doi.org/10.1007/978-3-662-59586-2_3.

European Commission. 2007. Simplified Tax Compliance Procedures for SMEs Personal Income Tax, Corporate Income Tax, Payroll Tax.

European Commission. 2019. Taxation trends in the European Union: 2018 edition, Taxation trends 2019, Directorate General Taxation and Customs Union, European Commission.

Ferede, E. 2018. The Effects on Entrepreneurship of Increasing Provincial Top Personal Income Tax Rates in Canada. Fraser Institute.

Ferede, E. 2019. Entrepreneurship and personal income tax: evidence from Canadian provinces. Small Business Economics.

Gentry, W.M. 2010. Capital Gains Taxation and Entrepreneurship. Law \& Economics Workshop Series, Boston University.

Henrekson, M., Johansson, D., Stenkula, M. 2010. Taxation, Labor Market Policy and HighImpact Entrepreneurship. Journal of Industry Competition and Trade, 10, 275-296. 10.1007/s10842-010-0081-2.

Hoskisson, R.E., Covin, J., Volberda, H.W., Johnson, R.A. 2011. Revitalizing Entrepreneurship: The Search for New Research Opportunities. Journal of Management Studies, 48(6), 1141-1168.

Leibfritz, W., Thornton, J., Bibbee, A. 1997. Taxation and Economic Performance. OECD Economics Department Working Papers, No. 176, OECD Publishing, Paris. https://doi.org/10.1787/668811115745.

Macek, R. 2014. The impact of taxation on economic growth: Case study of OECD Countries. Review of Economic Perspectives, 14(3), 309-328.

Mohammadi Khyareh, M. 2018. Determinants of female entrepreneurship in Iran: An institutional approach. Economic Annals, 63, 111-129. DOI: 10.2298/EKA1816111K.

Myles, G.D. 2000. Taxation and Economic Growth. Fiscal Studies, 21(1), 141-168.

Razmi, S.M.J., Firoozabadi, S. 2016. Investigating the effect of education on women's entrepreneurship. International Journal of Learning and Intellectual Capital, 13(2), 273-288.

Romero Martínez, A.M., Milone, M. 2016. El emprendimiento en España: Intención emprendedora, motivaciones y obstáculos. Journal Globalization, Competitiveness and Governability, 10(1), 95-109.

Schetter, U., Gersbach, H., Schneider, M.T. 2019. Taxation, Innovation, and Entrepreneurship. The Economic Journal, 129(620), 1731-1781.

Thurik, R. 2014. Entrepreneurship and the business cycle. IZA World of Labor 2014: 90. doi: 10.15185/izawol.90.

Venancio, A., Barros, V., Raposo, C. 2020. Reducing corporate taxes - a boost for high quality entrepreneurship. Voxeu.org. 